\title{
Damage- and Pathogen-Associated Molecular Patterns and Alarmins: Keys to Sepsis?
}

\author{
S. Denk M. Perl M. Huber-Lang \\ Department of Traumatology, Hand, Plastic and Reconstructive Surgery, University of Ulm, Ulm, Germany
}

\section{Key Words}

Damage-associated molecular patterns .

Pathogen-associated molecular patterns $\cdot$ Alarmins •

Sepsis · Complement

\begin{abstract}
The concept that sepsis is the result of an uncontrolled inflammatory response of the host's innate immune system towards invading pathogens has recently been challenged. Evidence is accumulating that, in addition, host-derived alarm molecules are released during sepsis- and traumaassociated cell death, thus triggering the host's immune response. The identification and characterization of exogenous as well as endogenous danger molecules allowed significant advances in our understanding of the pathophysiology of sepsis and may provide potential targets for therapeutic interventions.

Copyright $\odot 2012$ S. Karger AG, Base
\end{abstract}

\section{New Definitions of Old Players: Damage- and Pathogen-Associated Molecular Patterns and Alarmins}

In 1891, the Russian scientist Elie Metchnikoff was the first to discover phagocytosis, a cell-mediated immune response against foreign microorganisms [1]. More than a century later, Charles Janeway proposed that the innate immune system uses evolutionarily ancient pattern recognition receptors such as Toll-like receptors (TLRs) and mannose receptors for the detection and identification of invading pathogens and their pathogen-associated molecular patterns (PAMPs) $[2,3]$. However, Janeway's model did not explain the immune response against 'self tissue' transplants, tumors, ischemia-related injuries or autoimmune diseases. In 2004, Seong and Matzinger [4] proposed that the immune system not only recognizes exogenous pathogens but also senses and responds to endogenous alarm signals released through cellular stress, trauma-induced tissue damage or nonphysiological cell death such as necrosis. This danger model is based on the fact that life evolved in water, which drives the hydrophobic portions (hyppos) of molecules to separate from water and aggregate with each other. Under physiological conditions, hyppos are hidden within lipid membranes of cells or other intracellular compartments. Although 'self' molecules are potentially immunoreactive, they are shielded within the cell, so that they are not sensed by the host immune system. However, the sudden exposure of intracellular molecules or their derivates on the outer leaflet acts as a sign of a potential danger of cellular damage [4]. Therefore, the recognition patterns of pathogens might be similar to those of released endogenous molecular structures, recognized by an evolutionarily ancient 'alarm system' for danger-associated molecular patterns.

\section{KARGER}

Fax +4161306 1234 E-Mail karger@karger.ch www.karger.com
(C) 2012 S. Karger AG, Basel

0014-312X/12/0484-0171\$38.00/0

Accessible online at:

www.karger.com/esr
Prof. Markus Huber-Lang

Clinical and Experimental Trauma-Immunology

University of Ulm, Helmholtzstrasse $8 / 2$

DE-89081 Ulm (Germany)

Tel.+49 731500 54716,E-Mail markus.huber-lang@uniklinik-ulm.de 
Although the detection of endogenous and exogenous alarm signals is possibly accomplished by the same early recognition systems, the source of danger remains different, causing some confusion and controversy about the terms damage-associated molecular patterns (DAMPs), PAMPs and alarmins. In regard to their discovery, the immunogenic foreign pathogen motifs were considered distinct from host-encoded molecules and therefore referred to as PAMPs, i.e. pathogen- (from Greek 'pathos' and 'genēs': 'producer of disease') associated molecular patterns [3]. Analogous, endogenous products released from dying or damaged cells were called DAMPs, i.e. damage- (from Latin 'damnum': 'loss, hurt') associated molecular patterns [4]. Based on the at least in part common recognition system and the similar inflammatory response, some authors use the term DAMPs as a unifying danger concept, integrating PAMPs with endogenous alarm signals. In this regard, the term alarmin (Italian 'all'arme': 'to arms') has been proposed to categorize endogenous DAMPs as separate from 'nonself' pathogen-derived molecules [5]. However, pathogen-associated exogenous derivates do not necessarily involve tissue damage, whereupon 'danger associated' would better reflect the common concept than 'damage associated'. We therefore use the term alarmin to differentiate the endogenous danger signals, which sense tissue and cell damage, from exogenous invading pathogens, unifying both in the large family of danger(from French 'dangier': 'power to harm') associated molecular patterns.

\section{Sepsis}

In the USA, sepsis is the second leading cause of death within noncoronary intensive care units, with increased mortality rates of between $20 \%$ for sepsis and $60 \%$ for septic shock [6]. Although the term 'sepsis' has been used for more than 2,700 years, the clinical definitions of sepsis were rather confusing and only inadequate. In 1991, standardized definitions for the various stages of sepsis were proposed to facilitate clinical assessment and ongoing research in this field [7]. Sepsis was defined as a clinical syndrome characterized by systemic inflammation (systemic inflammatory response syndrome, SIRS) with detection of bacteria. SIRS is manifested by two or more of the following conditions: hyperthermia $\left(>38.3^{\circ} \mathrm{C}\right)$ or hypothermia $\left(<35.5^{\circ} \mathrm{C}\right)$, tachycardia ( $>90$ beats $\left./ \mathrm{min}\right)$, tachypnea ( $>20$ breaths/min) and white blood count $>12,000 / \mathrm{mm}^{3}$ or $<4,000 / \mathrm{mm}^{3}$ or with $>10 \%$ immature neutrophils. Later concepts such as the predisposition, insult/infection, response and organ dysfunction model also include predisposing factors and premorbid conditions [8].

The underlying pathophysiology of both SIRS and sepsis is rooted in the body's innate immune system. Unlike the adaptive immune system, innate immunity is ready to immediately respond once immune cells encounter molecular patterns typical of invading pathogens or endogenous alarm signals from damaged cells [2] (fig. 1). The recognition of these DAMPs by recognition receptors of the innate immune system (danger sensing) results in an early activation of various serine protease systems such as the coagulation and complement cascades [9]. The subsequent activation of the 'first line of cellular defense' leads to an excessive activation of various intracellular signaling pathways and the release of cytokines and chemokines, accompanied by a complex neuroendocrine reaction [10]. In particular, cytokines and the transmigration of neutrophils and monocytes may result in endothelial dysfunction, causing vasodilatation and increased capillary permeability. The resulting leakage syndrome is clinically associated with hypotension, hemoconcentration, macromolecular extravasation and global edema [11, 12] (fig. 2). The dysfunctional endothelial barriers (blood-brain, blood-lung, blood-bowel and blood-urine barriers) enable further invasion by microorganisms and their products, thus disturbing the body's regulatory mechanisms on a molecular, cellular, tissue, organ and multiorgan level (fig. 2).

Recent findings suggest that the patient's response to sepsis involves both pro- and anti-inflammatory processes [13]. In this regard, sepsis results in a cascade of immune-modulatory events dominated by a hyperinflammatory state and the production of proinflammatory cytokines, including interleukin (IL)-1 $\beta$, IL- 6 and tumor necrosis factor (TNF)- $\alpha$ [14]. Almost simultaneously with the initial hyperinflammatory response, generation of anti-inflammatory cytokines occurs, including IL-10, followed by apoptosis of immune effector cells [14]. IL-10 has been shown to predict poor outcome in septic patients, and modulation of IL-10 in animal models of sepsis was found to improve survival.

Enhanced levels of various inflammatory markers such as IL-6, TNF- $\alpha$ or C-reactive protein have been identified in patients with sepsis as correlating with the clinical outcome [15]. However, none of these factors was an ideal sepsis marker as they were all indicators of inflammation rather than infection, and none was proven to be $100 \%$ specific for sepsis. Based on the danger mod- 
Fig. 1. Host response to molecular danger. Exogenous (pathogens) and endogenous (alarmins) danger-associated molecular patterns are recognized by the host's innate immune system, resulting in a systemic immune response, clinically manifested as sepsis.

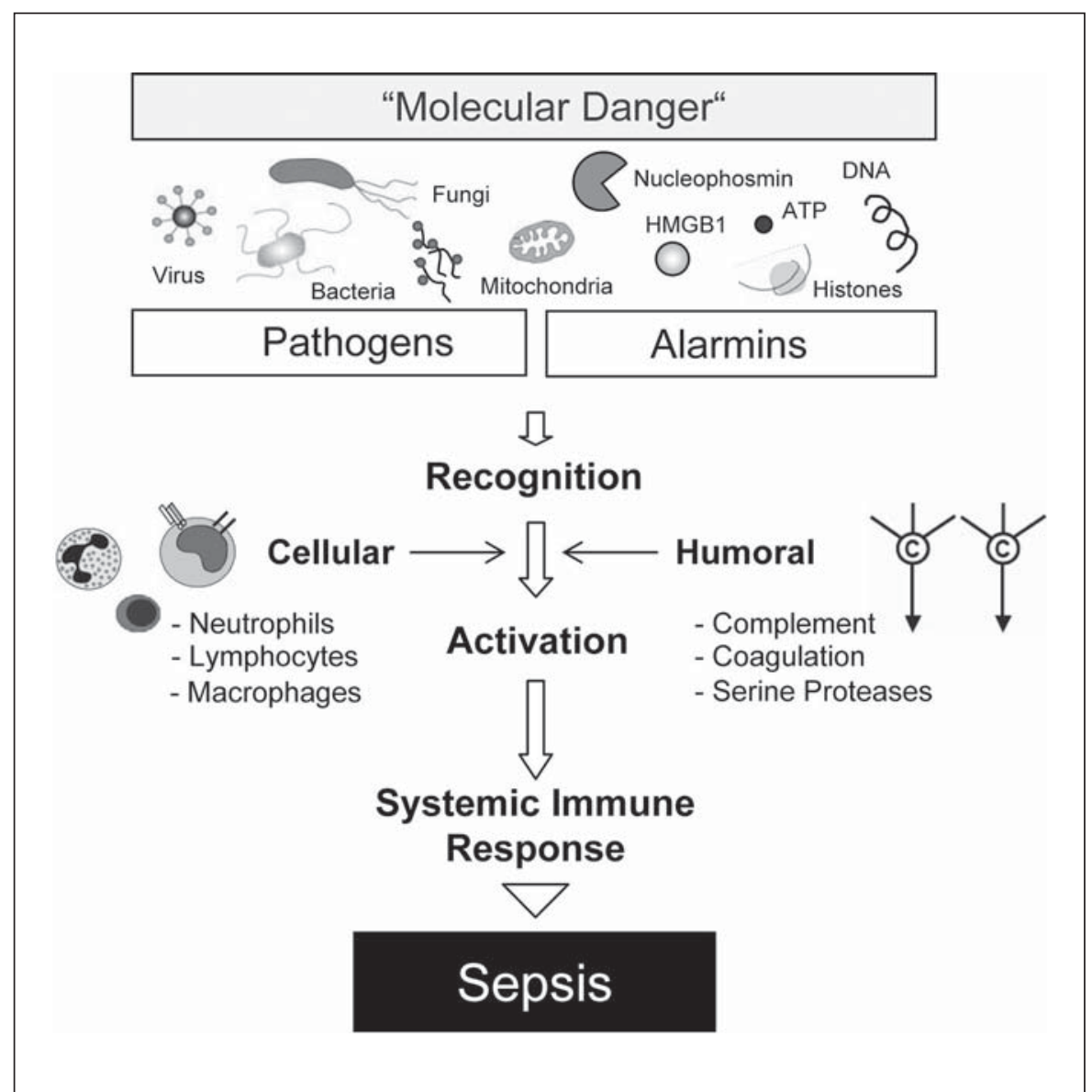

el, the search for adequate surrogate sepsis markers was expanded to endogenous biomarkers that are released into the circulation as a sign of danger in the case of sepsis.

\section{Exogenous PAMPs in Sepsis}

PAMPs are molecular motifs consistently found on pathogens. They are recognized by pattern recognition receptors of the innate immune system and represent an important molecular trigger in the development of sepsis [16]. Until the early 1980s, Gram-negative bacteria were proposed as the main inducers of sepsis; however, the incidence of sepsis caused by Gram-positive bacteria and fungi has steadily increased in recent years [6].

\section{Gram-Negative Bacteria}

The cell wall of Gram-negative bacteria consists of a thin peptidoglycan layer and an additional outer mem- brane composed of lipopolysaccharide (LPS), phospholipids and proteins. LPS (in particular the lipid A moiety) acts as an endotoxin and is responsible for the inflammatory response observed during endotoxic shock [17]. Upon its release, LPS activates complement, associates with serum LPS-binding protein and binds to the membrane receptor CD14 and the accessory molecule MD2, inducing TLR4 signaling. Bacteria-derived flagellin stimulates TLR5 [18], whereas peptidoglycan derivatives from Gram-negative bacteria are recognized by complement [19] as well as cytosolic nucleotide-binding oligomerization domain receptor [20]. Furthermore, unmethylated CpG DNA from Gram-negative and Gram-positive bacteria leads to TLR9 activation and plays an important role during infection with Gram-negative bacteria [21].

\section{Gram-Positive Bacteria}

The cell walls of Gram-positive bacteria mainly contain peptidoglycan with alternating $\mathrm{N}$-acetylglucosamine and $\mathrm{N}$-acetylmuramic acid, forming a mesh-like 


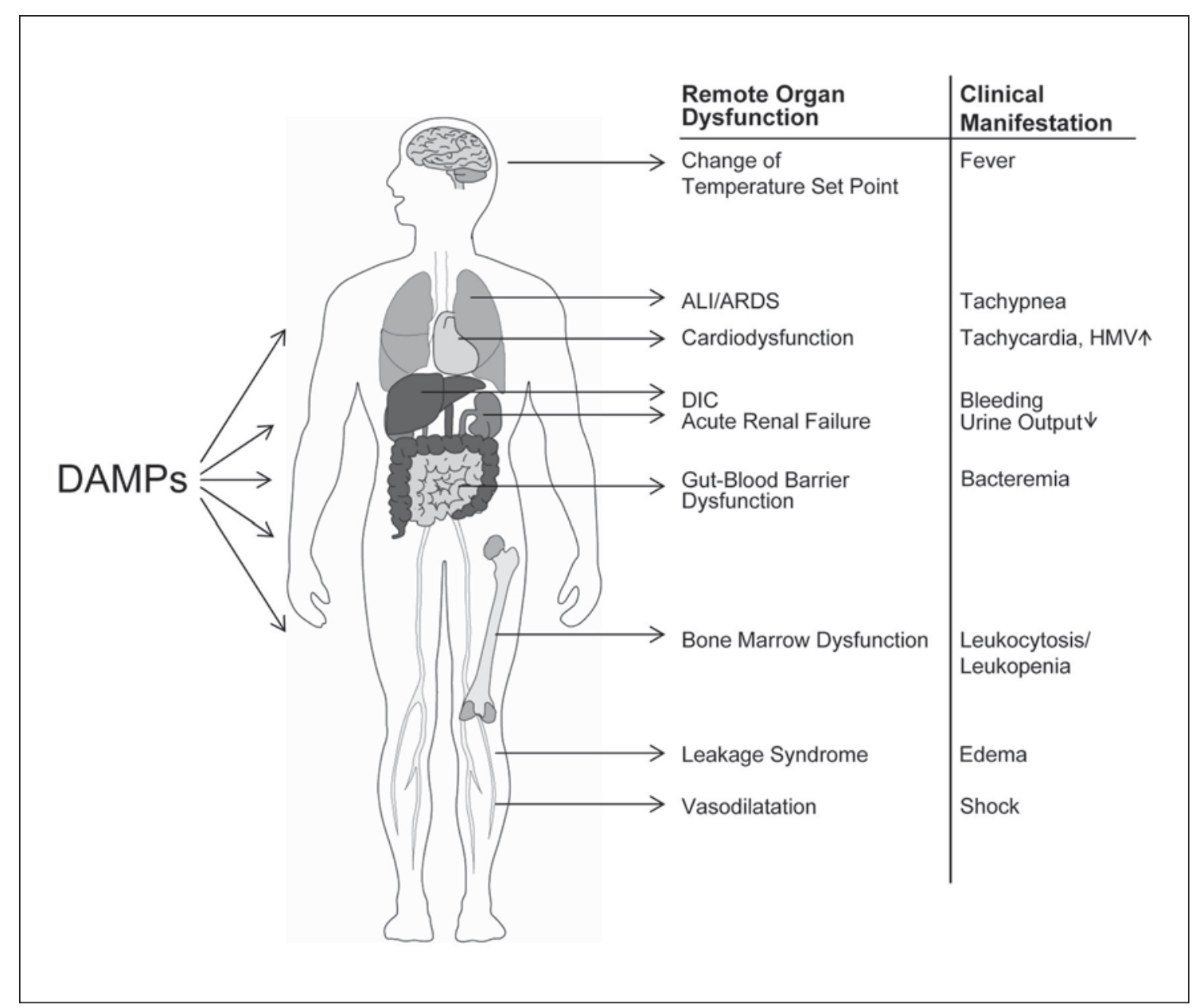

Fig. 2. DAMP-associated changes in organ function and resulting clinical signs. ALI = Acute lung injury; $\mathrm{ARDS}=$ acute respiratory distress syndrome; $\mathrm{HMV}=$ heart minute volume.

layer surrounding the cytoplasmic membrane. Cell wall PAMPs from Gram-positive bacteria, including lipoteichoic acid, lipoproteins and peptidoglycan, are recognized by complement and TLR2 [19, 22]. In addition, peptidoglycan derivatives are also able to activate cytosolic nucleotide-binding oligomerization domain-2 and the NACHT, LRR and PYD domains-containing protein 1 (NALP1) inflammasome, triggering a potent inflammatory response [23].

\section{Fungi}

In addition to dectin-1, pentraxin, mannose and various complement receptors, TLR2 and TLR4 have been implicated in innate immune responses towards various fungal pathogens and PAMPs structurally involved in the fungal cell surface [24]. In particular, the yeast cell wall component zymosan and Candida albicans-derived mannan lead to TLR $2 / 6$ and TLR4 activation, respectively [24]. Hereby, two different classes of pattern recognition receptors cooperate closely with each other, as the mannose receptor or the lectin receptor dectin-1 on phagocytes induces pathogen internalization, whereas intracellular TLRs trigger the inflammatory response via activation of NF- $\kappa B$ [25].

\section{Viruses}

Although bacteria are the most common cause of the development of sepsis, viruses can also be involved in such infectious processes. Viruses exhibit several structurally diverse molecular patterns, including surface glycoproteins as well as immunostimulatory nucleotides from the virion itself or produced during viral replica- 
tion. Whereas the viral nucleotides are recognized by intracellular receptors, virus-specific glycoproteins are detected by membrane-associated TLR2 and TLR4 $[17,26]$. In detail, viral DNA is recognized by TLR9 and DNAdependent activator of interferon (IFN)-regulatory factors, while single-stranded RNA activates TLR7 and TLR8. Double-stranded RNA and 5'-triphosphate RNA are detected by RIG-I-like receptors, TLR3 and the prokineticin receptor $[26,27]$.

\section{Endogenous DAMPs in Sepsis}

In addition to exogenous PAMPs, the host immune system faces endogenous danger-associated molecular patterns. These can be passively released during sepsisassociated ischemia and necrosis or actively secreted as endogenous alarm signals to warn the host of danger.

\section{DNA}

Historically, DNA was considered to be immunologically inert. Today it is well known that DNA can be recognized by the innate immune system. Autologous DNAchromatin complexes have been shown in vitro to stimulate proinflammatory cytokine release from endothelial cells and splenocytes [28]. TLR9 appears to be responsible for these stimulatory effects of exogenous as well as endogenous DNA [29], as this receptor recognizes not only unmethylated DNA sequences of microbes but also some similar sequences that have a very limited presence in mammalian DNA. There is some evidence indicating the presence of sensors for released cytosolic DNA that may initiate innate immune responses. Takaoka et al. [30] proposed DNA-dependent activator of IFN-regulatory factors as being a cytoplasmic recognition receptor for double-stranded DNA, leading to type I IFN gene expression by the induction of IFN-regulatory factor 3 and the TANK-binding kinase 1 pathway. Investigations of plasma DNA levels of critically ill patients revealed significantly higher DNA levels in those patients who developed sepsis compared to patients who did not and an overall negative correlation with survival [31].

\section{Histones}

$\mathrm{Xu}$ et al. [32] found that histones released extracellularly in response to inflammatory processes are involved in sepsis-induced endothelial dysfunction, organ failure and death. Activated neutrophils are regarded as a possible source of histones, as they were found to generate neutrophil extracellular traps during sepsis [33]. Neutro- phil extracellular traps are networks of extracellular fibers, primarily composed of neutrophil DNA and antimicrobial proteins which are capable of killing pathogens extracellularly independently of phagocytic uptake [34]. Another source might be derived from increased apoptosis, necrosis or severe tissue injury overwhelming the phagocytic system and subsequently permitting histones to enter the bloodstream [35]. In mice, the administration of a sublethal dose of histones resulted in neutrophil margination and accumulation, vacuolated endothelium and intra-alveolar hemorrhage [32]. Antibodies against histone 4 reduced the mortality in LPS-, TNF- $\alpha$ - and cecal ligation and puncture (CLP)-induced models of murine sepsis [32].

\section{Nucleophosmin}

Nucleophosmin (NPM) is a ubiquitously expressed phosphoprotein belonging to the nucleoplasmin family of chaperones [36]. NPM is mainly localized within the granular regions of the nucleolus, although portions of the protein shuttle between the nucleus and cytoplasm during the cell cycle [37]. NPM is involved in various cellular processes, including histone assembly, ribosome biogenesis, cell cycle progression, apoptosis and cell differentiation. Although the role of NPM in various cellular processes is well characterized, little is known about its role during sepsis. Nawa et al. [38] demonstrated for the first time that NPM exhibits a dual function similar to the high-mobility group box 1 (HMGB1) protein. With regard to its regulatory role during cell homeostasis, NPM is released into the extracellular space from RAW264.7 cells after LPS stimulation. Furthermore, NPM was found in a CLP-induced sepsis model in rats and triggered intercellular adhesion molecule-1 expression on the surface of human umbilical vein endothelial cells. In addition, NPM induced the release of cytokines such as TNF- $\alpha$, IL- 6 and monocyte chemotactic protein-1 via different mitogen-activated protein kinase (MAPK) pathways in RAW264.7 cells, indicating that NPM release from necrotic or activated cells might play an important role in the induction and maintenance of systemic inflammatory processes during sepsis.

\section{HMGB1}

HMGB1 is a nuclear binding protein that facilitates gene transcription by stabilizing nucleosome formation [39]. It can be actively released from leukocytes and dendritic cells upon LPS stimulation, resulting in the production of proinflammatory mediators [40]. In addi- 
tion, HMGB1 can be passively released from necrotic or damaged cells [41]. HMGB1 is recognized by TLR2/ TLR4 and the cellular receptor for advanced glycation end products, inducing different protein kinase pathways [c-Jun N-terminal kinase (JNK), extracellular signal-regulated kinases 1/2 (ERK1/2), p38 MAPK] and the activation of $\mathrm{NF}-\kappa \mathrm{B}[40,42]$. In endothelial cells, HMGB1 activates the expression of vascular cell adhesion molecule- 1 and intercellular adhesion molecule-1 [43], increasing the permeability of the endothelium and permitting bacterial translocation through endothelial barriers. The importance of HMGB1 in sepsis was originally indicated by its detection in murine models of endotoxemia or CLP $[40,44]$. Serum HMGB1 was first detectable $8 \mathrm{~h}$ after endotoxin administration and was significantly increased from 16 to $32 \mathrm{~h}$ after endotoxin infusion [40]. In clinical settings, HMGB1 levels were significantly elevated in the serum of critically ill patients with sepsis compared to healthy volunteers and correlated negatively with survival [40]. In experimental sepsis, treatment with anti-HMGB1 antibodies administered as late as $24 \mathrm{~h}$ after CLP has been proposed to significantly increase the survival rate of mice [45]. Of note, even such a late administration of anti-HMGB1 rescued animals that had already developed clear signs of sepsis, indicating a potentially wide window for therapeutic intervention [46].

\section{Mitochondria as 'the Enemies Within'}

According to the endosymbiont hypotheses, mitochondria are evolutionarily derived from $\alpha$-proteobacteria [47]. Therefore, mitochondria still bear many morphological and biochemical characteristics of their ancestors such as a circular genome containing nonmethylated CpG motifs and the ability to form $\mathrm{N}$-formylated peptides (NFPs) [48]. Therefore, it is not surprising that mitochondria released into the circulatory system lead to activation of the innate immune system similar to the pathways following PAMP exposure. Indeed, intravenous injection of mitochondrial DNA and NFPs in rats resulted in systemic inflammation, suggesting that the body's immune response induced by mitochondrial components mimics the immune response of bacterial sepsis [49]. In addition, plasma mitochondrial DNA concentrations in major trauma patients were several thousand times higher than in healthy controls [49], indicating a damage-induced release of NFPs. Similar to their bacterial ancestors, mitochondria-derived mitochondrial DNA and NFPs are recognized by TLR9 [50] or high-affinity formyl peptide receptors [51], respectively. Thereby, they induce the phosphorylation of p38, p44 and p42 MAPKs, resulting in neutrophil chemotaxis and the release of inflammatory mediators $[49,51]$.

\section{Adenosine Triphosphate}

Extracellular adenosine triphosphate (ATP) may be considered a further DAMP that can be released from cells or mitochondria upon cellular damage [52]. In addition, certain secretory organelles store large amounts of ATP that are secreted as a danger alarm signal [53]. ATP triggers macrophages, neutrophils and dendritic cells via the P2RX7 receptor to assemble the NALP3 inflammasome, resulting in activation of IL-1 $\beta$ and IL-18 and release of IL-1 $\alpha[54,55]$. IL-1 $\beta$ exhibits some pyrogenic function and is a key player in the processes of inflammation. In turn, IL-1 $\beta$ and IL- $1 \alpha$ can stimulate IL-1 receptor signaling, resulting in the generation of proinflammatory cytokines and chemokines, further stimulating the innate immune response.

\section{Danger Translation and Response}

The exposure of the host to endogenous as well as exogenous danger molecules leads to activation of a variety of recognition receptors such as TLRs and complement receptors expressed on monocytes, macrophages, dendritic cells and neutrophils as a first line of defense. In general, the activation of these immune cells results in the production of various proinflammatory cytokines and/ or chemokines, including TNF- $\alpha$, IL-1 $\beta$, IL- 6 and IL-8, lipid mediators, oxygen radicals and tissue-damaging enzymes [56]. A main danger sensing system is presented by the complement system [57].

Complement uses the 'pattern recognition' strategy via Clq and mannose-binding lectin, which both recognize pathogen-derived structures. In addition, the lack of host-specific complement-regulatory proteins leads to induction of the complement system [58]. Excessive complement activation is regarded as a central trigger for the development of sepsis $[59,60]$. In the clinical setting, increased plasma concentrations of the complement activation products $\mathrm{C} 3 \mathrm{a}$ and $\mathrm{C} 5 \mathrm{a}$ were associated with poor outcome [61]. In particular, the anaphylatoxin C5a exhibits various detrimental effects on the host's immune system (e.g. neutrophil dysfunction and immunoparalysis, thymocyte apoptosis, coagulopathy and multiorgan failure) [62], whereas the blockade of C5a or C5a-C5aR interaction improved cellular and organ function and survival in experimental murine sepsis [60]. 
To efficiently respond to danger, complement synergistically cooperates with TLRs [63] and the coagulation system [64], all of which are involved in the initiation and progression of the inflammatory response in sepsis. For example, complement anaphylatoxins enhance TLR signaling at the level of MAPKs, specifically ERK1/2 and JNK [65]. Vice versa, induction of TLRs activates the expression of complement factors and receptors [66]. The systemic administration of TLR agonists into decay-accelerating factor-deficient mice resulted in significantly increased TNF- $\alpha$, IL-1 $\beta$ and IL- 6 responses [65]. In addition, C5a-induced TLR cross talk might also involve $\mathrm{C} 5 \mathrm{~L} 2$, as it contributes synergistically with C5aR to the inflammatory response in CLP-induced sepsis [60].

In the course of danger-associated activation of the innate immune response, disseminated intravascular coagulation (DIC) has been recognized as a major complication during sepsis [67]. In response to inflammatory processes, tissue factor is excessively expressed on endothelial cells, monocytes and macrophages, playing a central role in the initiation of DIC. Subsequent thrombin activation leads to intra- and extravascular fibrin formation, followed by platelet dysfunction and the consumption of coagulation factors. DIC then results in microvascular fibrin deposition, often leading to defective microcirculation [68]. Furthermore, activated coagulation proteins such as thrombin, factor Xa and tissue factor VIIa can stimulate cytokine production, which in turn can stimulate the coagulation cascade. Activated platelets can secrete chemokines, express adhesion molecules on the endothelium and promote neutrophil adherence [69].

Like TLRs, the coagulation system cross talks intensively with the complement cascade [64]. Complement activation products amplify coagulation and inhibit fibrinolysis, mainly through $\mathrm{C} 5 \mathrm{a}$, which induces the expression of tissue factor [70] and plasminogen activator inhibitor 1 [71]. In addition, mannose-binding proteinassociated serine protease 2 activates both the complement and coagulation cascades, generating thrombin [72]. Vice versa, components of the coagulation system can amplify complement activation. Activated clotting factor XII triggers the classical complement pathway via C1 cleavage [73], whereas thrombin directly cleaves C5, generating biologically active anaphylatoxin C5a [74]. In this regard, a recent study further indicates novel cross talk between the complement and apoptosis systems. Hereby, the apoptosis-inducing factor granzyme B was shown to be capable of generating $\mathrm{C} 3 \mathrm{a}$ and $\mathrm{C} 5 \mathrm{a}$ independently of the established complement activation pathways [75]. Therefore, the complement, coagulation and apoptosis cascades interact synergistically with each other, forming a 'serine protease network' which may play an important role in the pathogenesis of sepsis [9].

\section{Conclusion}

Recently, there has been considerable progress in identifying novel endogenous DAMPs that are implicated in the pathogenesis of inflammatory diseases such as sepsis. Endogenous DAMPs can be passively released as a result of nonphysiological cell death or actively secreted as alarm signals (alarmins) to warn the host of danger by activating the innate immune response. In this regard, DNA, histones or mitochondria might be useful surrogate markers for the development and progression of sepsis. However, most endogenous DAMPs arise from cellular breakdown due to any kind of cellular damage, which can be the result of severe tissue trauma or various inflammatory processes apart from sepsis. Thus, DAMPs might exhibit potent targets for therapeutic interventions. The administration of HMGB1-neutralizing antibodies or inhibitors has been beneficial in experimental sepsis [46], although the underlying mechanisms are not fully understood. The inflammatory response in sepsis is a complex interplay of different host defense systems and their mediators, such as the complement, TLR and coagulation systems, resulting in a severe dysregulation of the immune-regulatory network. A deeper understanding of the underlying pathways is necessary to provide new insights to modulate the DAMP response and to develop novel management strategies to effectively improve the clinical outcome of sepsis in the future.

\section{Acknowledgements}

This work was supported by grants from the Deutsche Forschungsgemeinschaft (DFG HU 823/3-2 to M.H.-L. and ENPE-908/2-1 to M.P.).

\section{Disclosure Statement}

None of the authors have any financial interests or affiliations with commercial organizations whose products or services are related to the subject matter of this paper (no existing conflicts of interest). 


\section{References}

-1 Tan SY, Dee MK: Elie Metchnikoff (18451916): discoverer of phagocytosis. Singapore Med J 2009;50:456-457.

2 Hansen JD, Vojtech LN, Laing KJ: Sensing disease and danger: a survey of vertebrate PRRs and their origins. Dev Comp Immunol 2011;35:886-897.

3 Janeway CA Jr: Approaching the asymptote? Evolution and revolution in immunology. Cold Spring Harb Symp Quant Biol 1989;54: $1-13$.

4 Seong SY, Matzinger P: Hydrophobicity: an ancient damage-associated molecular pattern that initiates innate immune responses. Nat Rev Immunol 2004;4:469-478.

$\checkmark 5$ Oppenheim JJ, Yang D: Alarmins: chemotactic activators of immune responses. Curr Opin Immunol 2005;17:359-365.

-6 Martin GS, Mannino DM, Eaton S, Moss M: The epidemiology of sepsis in the United States from 1979 through 2000. N Engl J Med 2003;348:1546-1554.

7 American College of Chest Physicians/Society of Critical Care Medicine Consensus Conference: definitions for sepsis and organ failure and guidelines for the use of innovative therapies in sepsis. Crit Care Med 1992; 20:864-874.

$\checkmark 8$ Angus DC, Burgner D, Wunderink R, Mira JP, Gerlach H, Wiedermann CJ, Vincent JL: The PIRO concept: P is for predisposition. Crit Care 2003;7:248-251.

9 Rittirsch D, Flierl MA, Ward PA: Harmful molecular mechanisms in sepsis. Nat Rev Immunol 2008;8:776-787.

10 Tracey KJ: Physiology and immunology of the cholinergic antiinflammatory pathway. J Clin Invest 2007;117:289-296.

-11 Rivers E, Nguyen B, Havstad S, Ressler J, Muzzin A, Knoblich B, Peterson E, Tomlanovich M: Early goal-directed therapy in the treatment of severe sepsis and septic shock. N Engl J Med 2001;345:1368-1377.

12 Henneke P, Golenbock DT: Innate immune recognition of lipopolysaccharide by endothelial cells. Crit Care Med 2002;30:S207S213.

-13 Kox WJ, Volk T, Kox SN, Volk HD: Immunomodulatory therapies in sepsis. Intensive Care Med 2000;26(suppl 1):S124-S128.

-14 Muenzer JT, Davis CG, Chang K, Schmidt RE, Dunne WM, Coopersmith CM, Hotchkiss RS: Characterization and modulation of the immunosuppressive phase of sepsis. Infect Immun 2010;78:1582-1592.

-15 Terregino CA, Lopez BL, Karras DJ, Killian AJ, Arnold GK: Endogenous mediators in emergency department patients with presumed sepsis: are levels associated with progression to severe sepsis and death? Ann Emerg Med 2000;35:26-34.

-16 Tsujimoto H, Ono S, Efron PA, Scumpia PO, Moldawer LL, Mochizuki H: Role of Toll-like receptors in the development of sepsis. Shock 2008;29:315-321.
17 Akira S, Uematsu S, Takeuchi O: Pathogen recognition and innate immunity. Cell 2006 124:783-801.

18 Hayashi F, Smith KD, Ozinsky A, Hawn TR, Yi EC, Goodlett DR, Eng JK, Akira S, Underhill DM, Aderem A: The innate immune response to bacterial flagellin is mediated by Toll-like receptor 5. Nature 2001;410:10991103.

19 Mattsson E, Rollof J, Verhoef J, Van DH, Fleer A: Serum-induced potentiation of tumor necrosis factor alpha production by human monocytes in response to staphylococcal peptidoglycan: involvement of different serum factors. Infect Immun 1994;62:38373843.

20 Chamaillard M, Hashimoto M, Horie Y, Masumoto J, Qiu S, Saab L, Ogura Y, Kawasaki A, Fukase K, Kusumoto S, Valvano MA, Foster SJ, Mak TW, Nunez G, Inohara N: An essential role for NOD1 in host recognition of bacterial peptidoglycan containing diaminopimelic acid. Nat Immunol 2003;4:702707.

21 Hemmi H, Takeuchi O, Kawai T, Kaisho T, Sato S, Sanjo H, Matsumoto M, Hoshino K, Wagner H, Takeda K, Akira S: A Toll-like receptor recognizes bacterial DNA. Nature 2000;408:740-745.

22 Schwandner R, Dziarski R, Wesche H, Rothe M, Kirschning CJ: Peptidoglycan- and lipoteichoic acid-induced cell activation is mediated by toll-like receptor 2. J Biol Chem 1999; 274:17406-17409.

23 Faustin B, Lartigue L, Bruey JM, Luciano F Sergienko E, Bailly-Maitre B, Volkmann N, Hanein D, Rouiller I, Reed JC: Reconstituted NALP1 inflammasome reveals two-step mechanism of caspase- 1 activation. Mol Cell 2007;25:713-724.

24 Roeder A, Kirschning CJ, Rupec RA, Schaller M, Korting HC: Toll-like receptors and innate antifungal responses. Trends Microbiol 2004; 12:44-49.

25 Underhill DM, Ozinsky A, Hajjar AM, Stevens $A$, Wilson $C B$, Bassetti $M$, Aderem $A$ : The Toll-like receptor 2 is recruited to macrophage phagosomes and discriminates between pathogens. Nature 1999;401:811-815.

26 Mogensen TH, Paludan SR: Reading the viral signature by Toll-like receptors and other pattern recognition receptors. J Mol Med (Berl) 2005;83:180-192.

-27 Kato H, Takahasi K, Fujita T: RIG-I-like receptors: cytoplasmic sensors for non-self RNA. Immunol Rev 2011;243:91-98.

28 Hefeneider SH, Cornell KA, Brown LE, Bakke AC, McCoy SL, Bennett RM: Nucleosomes and DNA bind to specific cell-surface molecules on murine cells and induce cytokine production. Clin Immunol Immunopathol 1992;63:245-251.
29 Leadbetter EA, Rifkin IR, Hohlbaum AM, Beaudette BC, Shlomchik MJ, MarshakRothstein A: Chromatin-IgG complexes activate B cells by dual engagement of IgM and Toll-like receptors. Nature 2002;416:603607.

30 Takaoka A, Wang Z, Choi MK, Yanai H, Negishi H, Ban T, Lu Y, Miyagishi M, Kodama T, Honda K, Ohba Y, Taniguchi T: DAI (DLM-1/ZBP1) is a cytosolic DNA sensor and an activator of innate immune response. Nature 2007;448:501-505

31 Saukkonen K, Lakkisto P, Pettila V, Varpula M, Karlsson S, Ruokonen E, Pulkki K: Cellfree plasma DNA as a predictor of outcome in severe sepsis and septic shock. Clin Chem 2008;54:1000-1007.

-32 Xu J, Zhang X, Pelayo R, Monestier M, Ammollo CT, Semeraro F, Taylor FB, Esmon NL, Lupu F, Esmon CT: Extracellular histones are major mediators of death in sepsis. Nat Med 2009; 15:1318-1321.

>33 Clark SR, Ma AC, Tavener SA, McDonald B, Goodarzi Z, Kelly MM, Patel KD, Chakrabarti S, McAvoy E, Sinclair GD, Keys EM, Allen-Vercoe E, Devinney R, Doig CJ, Green FH, Kubes P: Platelet TLR4 activates neutrophil extracellular traps to ensnare bacteria in septic blood. Nat Med 2007;13:463-469.

-34 Brinkmann V, Reichard U, Goosmann C, Fauler B, Uhlemann Y, Weiss DS, Weinrauch Y, Zychlinsky A: Neutrophil extracellular traps kill bacteria. Science 2004;303:15321535.

35 Chaput C, Zychlinsky A: Sepsis: the dark side of histones. Nat Med 2009;15:1245-1246.

>36 Frehlick LJ, Eirin-Lopez JM, Ausio J: New insights into the nucleophosmin/nucleoplasmin family of nuclear chaperones. Bioessays 2007;29:49-59.

-37 Kerr LE, Birse-Archbold JL, Short DM, McGregor AL, Heron I, Macdonald DC, Thompson J, Carlson GJ, Kelly JS, McCulloch J, Sharkey J: Nucleophosmin is a novel Bax chaperone that regulates apoptotic cell death. Oncogene 2007;26:2554-2562.

38 Nawa Y, Kawahara K, Tancharoen S, Meng $\mathrm{X}$, Sameshima H, Ito T, Masuda Y, Imaizumi H, Hashiguchi T, Maruyama I: Nucleophosmin may act as an alarmin: implications for severe sepsis. J Leukoc Biol 2009;86:645653.

-39 Andersson U, Erlandsson-Harris H, Yang H, Tracey KJ: HMGB1 as a DNA-binding cytokine. J Leukoc Biol 2002;72:1084-1091.

-40 Wang H, Bloom O, Zhang M, Vishnubhakat JM, Ombrellino M, Che J, Frazier A, Yang H, Ivanova S, Borovikova L, Manogue KR, Faist E, Abraham E, Andersson J, Andersson U, Molina PE, Abumrad NN, Sama A, Tracey KJ: HMG-1 as a late mediator of endotoxin lethality in mice. Science 1999;285: 248-251 
-41 Rovere-Querini P, Capobianco A, Scaffidi P, 52 Willart MA, Lambrecht BN: The danger Valentinis B, Catalanotti F, Giazzon M, Dumitriu IE, Muller S, Iannacone M, Traversari C, Bianchi ME, Manfredi AA: HMGB1 is an endogenous immune adjuvant released by necrotic cells. EMBO Rep 2004;5:825-830.

$\checkmark 42$ Zurolo E, Iyer A, Maroso M, Carbonell C, Anink JJ, Ravizza T, Fluiter K, Spliet WG, van Rijen PC, Vezzani A, Aronica E: Activation of Toll-like receptor, RAGE and HMGB1 signalling in malformations of cortical development. Brain 2011;134:1015-1032.

-43 Fiuza C, Bustin M, Talwar S, Tropea M, Gerstenberger E, Shelhamer JH, Suffredini AF: Inflammation-promoting activity of HMGB1 on human microvascular endothelial cells. Blood 2003;101:2652-2660.

44 Abraham E, Arcaroli J, Carmody A, Wang H, Tracey KJ: HMG-1 as a mediator of acute lung inflammation. J Immunol 2000;165: 2950-2954.

-45 Yang H, Ochani M, Li J, Qiang X, Tanovic M, Harris HE, Susarla SM, Ulloa L, Wang H, DiRaimo R, Czura CJ, Wang H, Roth J, Warren HS, Fink MP, Fenton MJ, Andersson U, Tracey KJ: Reversing established sepsis with antagonists of endogenous high-mobility group box 1. Proc Natl Acad Sci USA 2004; 101:296-301

46 Wang H, Yang H, Tracey KJ: Extracellular role of HMGB1 in inflammation and sepsis. J Intern Med 2004;255:320-331.

-47 Gray MW, Burger G, Lang BF: Mitochondrial evolution. Science 1999;283:1476-1481.

48 Krysko DV, Agostinis P, Krysko O, Garg AD, Bachert C, Lambrecht BN, Vandenabeele P: Emerging role of damage-associated molecular patterns derived from mitochondria in inflammation. Trends Immunol 2011;32: 157-164.

49 Zhang Q, Raoof M, Chen Y, Sumi Y, Sursal T, Junger W, Brohi K, Itagaki K, Hauser CJ: Circulating mitochondrial DAMPs cause inflammatory responses to injury. Nature 2010;464:104-107.

-50 Collins LV, Hajizadeh S, Holme E, Jonsson IM, Tarkowski A: Endogenously oxidized mitochondrial DNA induces in vivo and in vitro inflammatory responses. J Leukoc Biol 2004;75:995-1000.

-51 Raoof M, Zhang Q, Itagaki K, Hauser CJ: Mitochondrial peptides are potent immune activators that activate human neutrophils via FPR-1. J Trauma 2010;68:1328-1332. within: endogenous danger signals, atopy and asthma. Clin Exp Allergy 2009;39:1219.

53 Novak I: ATP as a signaling molecule: the exocrine focus. News Physiol Sci 2003;18:1217.

54 Martinon F: Detection of immune danger signals by NALP3. J Leukoc Biol 2008;83: 507-511.

55 Dinarello CA: Infection, fever, and exogenous and endogenous pyrogens: some concepts have changed. J Endotoxin Res 2004; 10:201-222.

56 Decker T: Sepsis: avoiding its deadly toll. J Clin Invest 2004;113:1387-1389.

57 Kohl J: The role of complement in danger sensing and transmission. Immunol Res 2006;34:157-176.

58 Klos A, Tenner AJ, Johswich KO, Ager RR, Reis ES, Kohl J: The role of the anaphylatoxins in health and disease. Mol Immunol 2009;46:2753-2766.

59 Flierl MA, Rittirsch D, Nadeau BA, Day DE, Zetoune FS, Sarma JV, Huber-Lang MS, Ward PA: Functions of the complement components C3 and C5 during sepsis. FASEB J 2008;22:3483-3490.

60 Rittirsch D, Flierl MA, Nadeau BA, Day DE, Huber-Lang M, Mackay CR, Zetoune FS, Gerard NP, Cianflone K, Kohl J, Gerard C, Sarma JV, Ward PA: Functional roles for C5a receptors in sepsis. Nat Med 2008;14:551-557.

61 Nakae H, Endo S, Inada K, Takakuwa T, Kasai T, Yoshida M: Serum complement levels and severity of sepsis. Res Commun Chem Pathol Pharmacol 1994;84:189-195.

62 Ward PA: The dark side of C5a in sepsis. Nat Rev Immunol 2004;4:133-142.

63 Hajishengallis G, Lambris JD: Crosstalk pathways between Toll-like receptors and the complement system. Trends Immunol 2010;31:154-163.

-64 Amara U, Flierl MA, Rittirsch D, Klos A, Chen H, Acker B, Bruckner UB, Nilsson B, Gebhard F, Lambris JD, Huber-Lang M: Molecular intercommunication between the complement and coagulation systems. J Immunol 2010;185:5628-5636.

65 Zhang X, Kimura Y, Fang C, Zhou L, Sfyroera $G$, Lambris JD, Wetsel RA, Miwa T, Song WC: Regulation of Toll-like receptormediated inflammatory response by complement in vivo. Blood 2007;110:228-236.
66 Kaczorowski DJ, Afrazi A, Scott MJ, Kwak JH, Gill R, Edmonds RD, Liu Y, Fan J, Billiar TR: Pivotal advance: the pattern recognition receptor ligands lipopolysaccharide and polyinosine-polycytidylic acid stimulate factor B synthesis by the macrophage through distinct but overlapping mechanisms. J Leukoc Biol 2010;88:609-618.

67 Levi M, Ten CH: Disseminated intravascular coagulation. N Engl J Med 1999;341:586592.

68 Abraham E: Coagulation abnormalities in acute lung injury and sepsis. Am J Respir Cell Mol Biol 2000;22:401-404.

-69 Lissauer ME, Johnson SB, Siuzdak G, Bochicchio G, Whiteford C, Nussbaumer B, Moore R, Scalea TM: Coagulation and complement protein differences between septic and uninfected systemic inflammatory response syndrome patients. J Trauma 2007; 62:1082-1092.

70 Ritis K, Doumas M, Mastellos D, Micheli A, Giaglis S, Magotti P, Rafail S, Kartalis G, Sideras P, Lambris JD: A novel C5a receptor-tissue factor cross-talk in neutrophils links innate immunity to coagulation pathways. J Immunol 2006;177:4794-4802.

71 Markiewski MM, Nilsson B, Ekdahl KN, Mollnes TE, Lambris JD: Complement and coagulation: strangers or partners in crime? Trends Immunol 2007;28:184-192.

72 Krarup A, Wallis R, Presanis JS, Gal P, Sim RB: Simultaneous activation of complement and coagulation by MBL-associated serine protease 2. PLoS One 2007;2:e623.

73 Ghebrehiwet B, Silverberg M, Kaplan AP: Activation of the classical pathway of complement by Hageman factor fragment. J Exp Med 1981;153:665-676.

74 Huber-Lang M, Sarma JV, Zetoune FS, Rittirsch D, Neff TA, McGuire SR, Lambris JD, Warner RL, Flierl MA, Hoesel LM, Gebhard F, Younger JG, Drouin SM, Wetsel RA, Ward PA: Generation of C5a in the absence of C3: a new complement activation pathway. Nat Med 2006;12:682-687.

75 Perl M, Denk S, Kalbitz M, Huber-Lang M: Granzyme B: a new crossroad of complement and apoptosis. Adv Exp Med Biol 2012;946: 135-146. 